\title{
PERCEPTIONS OF TEACHER AND STUDENTS ON THE USE OF E-MAIL AS A MEDIUM IN DISTANCE LEARNING
}

\author{
Nashruddin ${ }^{1 *}$, Fiptar Abdi Alam ${ }^{2}$, Novalia Tanasy ${ }^{3}$ \\ ${ }^{1}$ STKIP Muhammadiyah Barru \\ ${ }^{2}$ STKIP Muhammadiyah Barru \\ ${ }^{3}$ Universitas Muslim Maros
}

\begin{tabular}{l}
\multicolumn{1}{c}{ Corresponding Author: Nas } \\
\hline ARTICLE INFO \\
Received:19-09-2020 \\
Accepted: 04-10-2020 \\
Published: October 2020 \\
Volume:3 \\
Issue: 2 \\
DOI: \\
https://doi.org/10.33019/berumpun.v3 \\
i1.40 \\
\hline KEYWORDS
\end{tabular}

ABSTRACT

e-mail, covid-19 pandemic, online learning, ELT

The covid-19 pandemic that hit the world including Indonesia has caused the teaching and learning system change from face-to-face in the classroom to distance learning or online learning. Online learning requires teachers and students to be able to use the information and communication technology (ICT). In ELT, the learning system is also implemented online. One of platforms commonly used in online communication is e-mail. This current study aims to describe: (1) teacher's perceptions about the use of e-mail as a learning medium in ELT, (2) students' perceptions about the use of e-mail as a learning medium in ELT. The subjects of this descriptive qualitative research were an EFL teacher and 20 students at a senior high school in Barru. For collecting data, the researchers applied questionnaire, documentation, and interview. Data was analyzed inductively or qualitatively. The results indicated the teacher's perceptions on the use of e-mail in learning that email is an effective device, e-mail can be used to send many documents, e-mail as a tool to achieve learning objectives, and e-mail makes learning easier. Students' perceptions on the use of e-mail are e-mail can be used for getting learning materials, e-mail is easy to use, and students can access various assignments on email. However, a small number of students still encountered obstacles in using email as a learning medium.

\section{INTRODUCTION}

The use of information and communication technology in the form of information systems is increasing and expanding in the people live. The development of information technology has influenced the entire pattern of life and culture of the community. The influence of information technology has been felt in various fields, such as education, community services, aviation services, tourism, banking, and other industries.

The field of communication is also inseparable from the use of information technology. According to Gallois, Ogay, and Giles (2005), the relationship between information technology and communication media is an expansive logic of development in the process of global public communication. The society can no longer avoid from the process of information and communication technology. 
Ashby (1972) argued that communication technology has caused the fourth revolution in the field of education. The first revolution occurred thousands of years ago since society differentiated the responsibilities of adults, and the task of educating the younger generation shifted from parents to teachers and from home to school. The second revolution occurred with the use of written language as a means of education, which previously, the education took place orally. The third revolution was marked by the invention of printing techniques which then enabled the widespread availability of books. The fourth revolution was marked by the electronic development, mainly in the form of radio, television, recording tape and computer.

The fourth revolution has been developing for three decades, and during that time has shown its futuristic characteristics Oborn and Johnson (2015). The new media has offered a number of acceptable and spectacular alternative problem solving. According to Howe and Strauss (2003), some implications of technological development for education are as follows:

1. Distance learning is developing

2. Student will have greater access from various sources

3. The library as a source of learning in various forms, will become a dominant feature on campus

4. The campus building will spread, with a core campus at the center, and a number of satellite campuses, which can generate intimacy in the community

5. The emergence of a new profession in the field of media technology

6. All students and all academicians will be motivated to master certain technology, at least computers

7. The candidates of teachers and lecturers are encouraged to master the use of instructional technology

8. The transfer of funds, for example the fund that originally to construct a new building was diverted for operational costs of teaching outside the campus.

9. Students are required to study more independently

10. More and better tests are needed, to assess the learning progress of students who are learning by using new technology

As a result of rapid technological progress, online learning is part of course offerings from many institutions throughout the world. Online learning or distance education by using the information and communication technology also applies in Indonesia. Based on data from the Ministry of Education and Culture of the Republic of Indonesia, in the early 2000 s, online learning has been applied in several educational institutions, not only at the level of higher education, but also secondary education (BBC, 2020).

At the higher education or university level, online learning is considered a new challenge at this time. Although this learning model has been applied since the early 2000s, this model has not yet been comprehensively covered all educational institutions in Indonesia. In addition, online learning also has special requirements, namely access to digital information. At present, Indonesia has not yet provided adequate and extensive infrastructure in the form of Information and Communication Technology for all its citizens, as the main prerequisites for distance learning or online learning. In addition, the 
ability of lecturers and students to use information technology is one of the factors that influence online learning (BBC, 2020).

In the early of 2020, the Covid-19 occurred in Indonesia, which caused all human activities to be limited, including learning activities. This forces the education system, from elementary school to university level, to carry out learning at home. This was done to limit the spread of massive viruses. The policy of home learning began to be implemented on March 9, 2020 after the Minister of Education and Culture issued a circular, number 2 and number 3 in 2020, about online learning online working from home in order to prevent the spread of Corona Virus Disease or Covid-19.

With this provision, teachers in schools and lecturers at universities carry out online learning. It is undeniable that all parties who undergo online learning feel panic, either lecturers or students (Press, 2020). That is because in general they are not ready as a whole to do online learning at this time. Technical problems that are usually encountered are quota constraints (internet balance), signals, media, and online applications that are used.

Higher education actually has a real responsibility for the survival of society. Aside from being a means of learning, on the other hand tertiary institutions also have a function to increase social solidarity between communities. For this reason, universities also have contributed in overcoming corona virus outbreaks. This covid-19 pandemic has returned the higher education to its ultimate classic mission of caring and universal social solidarity.

The use of information and communication technology in the teaching and learning process (education) seems to have become a necessity, especially during a pandemic like nowadays. Various media can be used by lecturers in carrying out online teaching. Each media certainly has advantages and disadvantages. In addition, students also have different abilities and experiences from one another in using online learning media. One of the online learning media commonly used is electronic mail or e-mail. Therefore, this study aims to describe the perceptions of teacher and students about the use of e-mail as a learning medium in ELT.

\section{LITERATURE REVIEW}

\subsection{An Overview of the Covid-19 Pandemic}

In early 2020, the whole world was shocked by the emergence of new virus, namely Corona Virus (SARS-CoV-2). This virus was first discovered in Wuhan, China, in December 2019. Therefore, the disease it causes is called Corona Virus Disease 2019 (Covid-19). At the end of March, it was reported that this virus had spread to 198 countries (updates, 2020).

According to Press (2020) in the study of the pattern of disease spread, there are several terms related to disease transmission, namely plague, endemic, epidemic, and pandemic. Plague is the emergence of a disease in society, namely a new unknown disease in the area. Plague is the smallest part of the disease transmission. Epidemic is actually similar to the plague but the range is wider and the transmission occurs quickly. An example is the case of the malaria epidemic in Liberia in 2003. At a broader level of spread, the epidemic turns into endemic. An example of an endemic is the Ebola case in subSaharan Africa.

Pandemics are epidemics that occur in a wide geographical area or spread globally (Press, 2020). A disease is declared a pandemic if the disease spreads around the world 
unexpectedly and people do not have immunity to the disease. Because Covid-19 has spread to 198 countries and infected more than 119,000 people in March 2020, WHO later declared the Covid-19 outbreak as a global pandemic (BBC, 2020).

Based on various studies, it is suspected that the main way of this disease spreading is through respiratory droplets and close contact with sufferers (Press, 2020). Droplets are small particles from the patient's mouth that can contain a viral disease, which is produced when coughing, sneezing, or talking. Therefore, people are required to wear cloth masks that cover the nose and mouth to prevent the spread of droplets.

One way to break the chain of spread of this disease is by staying at home. This means all activities must be done at home. People should not leave home. From this situation, the terms of worship at home, work from home, and learning at home emerged. Everyone seems to agree that the chain of spread of this disease virus must be cut of, and one of the ways to do that is staying at home.

In Indonesia, Covid-19 Pandemic has resulted in fundamental policy changes in various sectors, including education. The Indonesian Minister of Education and Culture, Nadiem Anwar Makarim has issued several policies to regulate learning activities during this pandemic condition. Among the several policies, the most basic is the policy of learning from home. This policy has greatly changed the habits or behavior of teachers and students so far (Citizen, 2020). Previously, the teacher taught in a school building that had a teaching and learning function, supported by learning tools. By this new policy, teachers are required to find the right pattern so that learning from home can be conducted.

This learning is very different from conventional learning. Teachers and students do not face each other directly, but in a distance which means that the teacher and students are in different places. The best way is to do learning activities based on the network, or also called online learning.

Positively, online learning is very helpful for the continuity of the learning process in this pandemic situation. Teachers and students will remain safe in their homes without having to leave the house and meet face to face. The main key to being able to carry out online learning is the ability to use information and communication technology.

The use of information and communication technology in teaching and learning process (education), including in ELT has become a necessity nowadays. Howe and Strauss (2003) stated that future education will be flexible, open, and accessible to everyone who needs it regardless of gender, age, and previous educational experience. Another feature is that future education will be more determined by the internet network, not by the school buildings. One feature is the use of e-mail which is an internet facility for learning purposes.

\subsection{Electronic Mail (E-mail)}

Electronic mail (e-mail) is an application that enables users to send and receive letters through an electronic address on the internet (Moran \& Hawisher, 1998). Every e-mail user has an electronic mailbox stored in a mail server. A mailbox has an address as an identifier in order to connect with other mailboxes. The message received will be accommodated in the mailbox, and then at any time, the owner of the mailbox can check its contents, answer messages, delete messages or edit and send e-mail messages. At present, sending letters through the internet using e-mail has become a familiar activity for the public. 
Chang and Hsu (1998) stated that e-mail has many benefits, including:

1. Effective for correspondence purposes.

It can be used for sending letters to several people at once with the same news content, for example: meeting agendas, product promotions, wedding invitations, and so on.

2. Having the efficiency to send large amounts of documents.

3. Flexible

E-mails can be sent, received or read anytime and anywhere

4. E-mail can be used to periodically subscribe to certain information, for example to monitor the product price information from a company

5. E-mail can be used to send work applications along with supporting document attachments, including photo

This opinion seems to receive a little criticism, especially on the point of efficiency in sending large documents. If it is talking in terms of quantity, e-mail is indeed quite efficient for sending many documents. However, if it is about the document with the large memory capacity, it seems that e-mail still has limited capabilities.

According to Purcell, Heaps, Buchanan, and Friedrich (2013) many people use email because it has practical value, speed in the process of sending mail, and it is costeffective. The process of sending email is only done in front of a computer at home or in an office that is connected to the internet. Users do not need to be bothered by letter printing, envelope purchases, stamps, and shipping to the post office box. Even though e-mail has the practicalities described above, there are weaknesses in it. The main thing is the area to operate it demands a stable internet network.

Another advantage of e-mail was revealed by Oomen and Early (2015) based on the results of their research. By using qualitative descriptive research methods on health science students, they found several advantages of e-mail. Multimedia documents can be sent by e-mail. In just seconds, the email has reached the destination address. The cost is also quite cheap, not reaching tens of thousands, even though the destination address has a great distance across other continents.

The result found by researchers mentioned above were supported by another study conducted by Barton, Fuller, and Schnitz (2015). By conducting interviews with several teachers who taught as children, their research results indicate that many e-mail facilities are provided free of charge at present.

With its many benefits, many teachers use e-mail as a learning medium, especially when online learning systems are applied. Another factor that must be considered in using e-mail is the internet network. To be able to send and receive e-mail messages, a computer device must be connected to the internet.

When a teacher will send the subject matter, his/her device must be connected to the internet. Meanwhile, the material will still be sent to student mailboxes even though they are not connected to the internet. However, to be able to open the message or material, they must be connected. This is one of the advantages of e-mail, because students do not have to open the material at the time, but they can do it anytime when they are connected to the network. This is one of the points indicated in a study conducted by Chun, Kern, and Smith (2016) which examines the use of information technology in education. However, in their research, they did not simply focus on e-mail usage. They concluded that, 
email is the same as other platforms, that all of them have advantages and disadvantages in their usage to support the field of education.

In ELT, there is writing course. In the course of writing, there are the subject of writing personal letters and the subject of writing official letters. After the teacher explained the theory of writing a letter, then students practiced it. Students must find friends to send e-mails to one another (Turnage \& Goodboy, 2014). Mails written by students must fulfill the letter elements, namely:

1. place and date

2. greetings

3. opening sentence

4. content

5. closing sentence

6. regards

7. signature

The letter must also contain phrases and idiom, and if possible the letter also contains proverbs in English. As a first step, students send e-mails to their peers. After there are suggestions, comments, input, and improvements from lecturers, and letters written by students are good, then continue writing e-mails to their teachers.

In addition to the use of e-mail in ELT as stated above, e-mail can also be used by students to submit assignments to their teachers. On the other hand, teachers also send subject materials and tasks via email. The teacher also did not bother to bring the student's assignment to his house to be corrected. The teacher only reads the mailbox, and then corrects the student's assignment. These are the results El-Sabban (2015) found in research he conducted on students at several universities. Students can do their assignment at home independently, and do not need to come to school. It seems that this conclusion still needs criticism. The criticism is related to providing information by the sender to the intended person. If all students have sent assignments via e-mail to a lecturer without confirming to the lecturer related, then the lecturer may not have opened the inbox for a long time so that the message may be accidentally deleted.

Studies on the use of email in education have been conducted out by previous researchers. Oborn and Johnson (2015) had carried out a study with the aim to evaluate the effects of developing multi component learning on the use of electronic mail on specific training and parenting strategies for various routines used during home-based learning. The researchers systematically tested the effects of two brief assignments conducted in 6 weeks of learning through performance feedback that was based on videotaped lesson materials and delivered via email. Findings provide support for the use of individualized coaching via performance feedback delivered in electronic format as a means to enhance learning outcome during.

Another study have been carried out by Barton et al. (2018) to evaluate the use of learning materials and tasks delivered via email which teachers recommended within inclusive early childhood classrooms. Results indicated that teaching and learning through email was an effective method for increasing teachers' use of target behaviors; however generalization and maintenance varied across teachers. 
McLeod, Kim, and Resua (2018) also had examine the influences of training and coaching through video and email feedback in teachers' use of recommended practices. Teachers investigated videos and provided email feedback with video examples of participants' use of the practices. The results of that study strengthen the evidence base for distance learning by using email as a viable support for teachers.

Those previous research results have provided an overview of the use of e-mail as a learning medium. In general, e-mail has many advantages to use. Apart from being flexible, e-mail also has other advantages in terms of efficiency and the ease of operation. However, based on preliminary observations, there were also some shortcomings of e-mail, including that confirmation of delivery was needed so that the documents sent were immediately accessed by the recipient. In addition, for its effective use, e-mail demands a stable quality internet network.

\section{METHODOLOGY}

This is a descriptive study, meaning that the current research is intended to describe a situation or certain population area that is factual, systematic or accurate. One of the dominant features of descriptive research is describing factual events (Johnson \& Christensen, 2008). The approach used in the current research is a qualitative approach.

This research was conducted at a senior high school in Barru, namely SMK Muhammadiyah Barru. The research subjects are a teacher of EFL with 20 students. Data collection techniques in this study were questionnaire, documentation, and interview. Questionnaire is used to get data about the form of e-mail usage in learning. Documentation is used to obtain data relating to the form and the use of e-mail in learning. Interview is conducted through online conversations to the teacher and students as respondents to obtain information to strengthen research data.

After the data collection and processing is complete, the next step is analyzing the data. In this research, data analysis is inductive or qualitative, in which qualitative research results emphasize more meaning than generalization.

\section{RESULTS AND DISCUSSION}

\subsection{Teachers' Perceptions}

From the results of data collection and analysis, teachers' perceptions about the use of email in learning, especially in pandemic conditions, were found as follows.

a. Email is an effective application for correspondence purposes

Based on the interview conducted to a teacher, the writer found information that email is an effective application to be used for correspondence purposes. In can be seen in the following extract:

\section{Extract 1}

Teacher : I have used several media to send and receive news online. Of all the media, I have found e-mail to be very effective. Its effectiveness lies in how quickly the message is received by the recipient. While online learning was implemented, I preferred to send assignment documents to students using email. I have also observed that students can easily send their 
According to that teacher, there is the subject of writing in English. In this subject, students are trained to be able to write letters according to the rules. During a pandemic like nowadays, sending letters is more effective through e-mail. E-mail also makes it easy for teachers to send subject material to students.

b. E-mail can be used to send many documents

The number of subjects and assignment causes the teacher to provide a lot of documents as well. When the online learning system is implemented, a large document must be sent to all students. By using the e-mail application, lots of material and documents can be sent easily to students. Likewise, students' assignment documents can be received by the teacher via e-mail. This information is consistent with the result of the interview with the teacher as shown in the following extract.

\section{Extract 2}

Teacher : I have many students. In online learning situations, students are still required to submit their written work. If the number of students is large, many different documents will be sent to me. The suitable medium for receiving multiple documents is e-mail.

\section{c. E-mail as a tool to achieve learning objectives}

Email helps the teacher to concretize the material received by students. It can be seen in the following extract:

\section{Extract 3}

Teacher : I used to use another application in online learning. I sent all materials through that media. However, some students did not immediately log into their devices and they were late in downloading the materials I sent, and the material document finally was deleted from their devices. This caused the learning objectives not achieved optimally. With e-mail, even though some students opened their inbox late, but the document is still stored in them can still access it in the next few days.

The teacher said that in distance learning system, without using media such as email, subject matter will be difficult for students to accept. Students will also quickly capture material messages sent by the teacher. E-mail is very helpful in achieving learning goals because it is easy to carry everywhere, practical, easy to remember, and fun for teachers.

d. E-mail makes learning easier 
When the distance learning system is applied, the choice is carrying out the online learning. E-mail has an important role and function in the online teaching and learning process. Students send their assignments to teachers using email. Thus, this makes it easy for teachers where the teacher does not bother carrying piles of papers produced by students' work. To check student work, the teacher just opens the mailbox anytime and anywhere.

The result of the interview to the teacher indicated the excellence in using e-mail as a learning medium based on the teacher's perceptions. This is in line with several previous research findings as mentioned in the previous section. However, there is a slight difference from several previous studies, namely the current study finds that e-mail can be a tool to achieve learning objectives.

\subsection{Students' Perception}

The results of this study indicate that most students' perceptions regarding the use of email in learning English in terms of the use of e-mail as a medium of learning classified as good because it is based on freedom indicator of choice in the use of the internet, students can use email to get learning material. The material was sent by their teacher. Students get subject matter by accessing their mailboxes.

According to students, email also provides learning resources which can be accessed anytime. This is in line with the results of teacher's perception. It can be seen in the following extract:

\section{Extract 4}

Student 1: In the conditions of online learning during this pandemic, I received assignment materials from the teacher via email. In the same way, I send my assignment documents to the teacher using email. I feel that email is good to be used as a learning medium.

In term of the use of email as a complement in learning English, students' perception is classified as good. This is because students have used email to send assignments to their teacher. Besides that, students can access remedial material and various assignments that have been sent by the teacher to their email address.

From the results of the questionnaire given to students, researchers found five reasons e-mails should be owned by students and teachers.

a. E-mail has now become one of the practical and efficient ways of communication. This statement is based on information obtained from students. One of them is indicated in the following extract:

\section{Extract 5}

Student 2 : Email is very efficient to use, both for sending and receiving documents. When the teacher has informed us of the delivery of material documents via email, the documents are immediately sent to our email inboxes. We can immediately download the document. 
b. Currently there are many devices besides computers that have the ability to receive and send e-mail, such as Smartphone and android.

Some students had been interviewed about the ease of email operation system. One of the interview results is shown below:

\section{Extract 6}

Student 3: Some students in our class do not yet have computers or notebooks. However, every student has android or Smartphone. Fortunately, android and Smartphone are also compatible to operate email. This means that email is a platform that is easy to operate on a variety of devices.

c. All matters require an immediate response today.

The student states that nowadays all information must be sent and received quickly. They have the perception that using e-mail is a fast way to send and receive documents. Even in seconds, sending letters and documents through electronic media can support this necessity, compared to conventional delivery systems. One of the interview results to students is shown below:

\section{Extract 7}

Student 4: Some friends complained about the slow delivery of documents if they use other applications. However, by using email, documents can be sent quickly. Likewise, the documents also arrive quickly to us via e-mail.

d. Users can set and determine who they want to receive e-mail from and how large files can be accepted.

One of the interviewed students gave information about e-mail, as shown in the following extract:

\section{Extract 8}

Student 5: I used to get unsolicited email messages from someone I didn't know. I later found out that I could set in my account the sending of e-mails from who is allowed to my e-mail address. I could also set how much document capacity is allowed to enter my email address.

e. Users can even delete junk e-mail from their mailboxes.

The results of interviews conducted with students show another advantage of email. It is shown in the extract below.

\section{Extract 9}

Student 6: Useless information, news and documents were often sent to my e-mail. In fact, there were also many junk e-mails that came into my inbox. But they could all be removed easily from an email account. 
From the results of interviews conducted with several students, the results obtained that students feel some obstacles or obstacles in the use of email. These constraints include:

a. Some students feel that face-to-face learning is more effective than using email. This is one of the students' perceptions about the weaknesses of using online media in learning, including email. The student stated that face-to-face learning was more effective than online learning system, whatever of the media used.

b. Some students found obstacles when they forgot their e-mail passwords Some students are new to using email. To be able to use email, the user must create an account consisting of a user name and password. Some students who are new to email sometimes forget their passwords. This makes it difficult for them to access their accounts so that they are too late to download materials sent by their teachers via email. They even could not access the subject matter and assignments that had been sent by the teacher to them.

c. Some students also found obstacles in terms of internet count.

Online learning requires students to stay at home and receive lessons from their teachers at their own homes. On the other hand, the teacher provides lesson also from his own house. This means that there is no direct meeting between the teacher and students.

This learning system requires media that is connected to the internet network. One such medium is e-mail. Same as other online media, e-mail can only work in areas with an internet network. Unfortunately, not all students live in the area covered by the internet network. Students said that those who live in the non-internet area have problems accessing the subject matter provided by the teacher using email.

\section{CONCLUSION}

From the results of research and discussion, it can be concluded that:

1. The teacher's perceptions regarding the use of email as a learning medium in this pandemic condition are:
a. Email is an effective application
b. E-mail can be used to send many documents
c. E-mail as a tool to achieve learning objectives
d. E-mail makes learning easier

2. The students' perceptions regarding the use of email as a learning medium in this pandemic condition are:
a. Email can be used to get learning materials
b. Email is easy to use for sending assignments to their teacher
c. Students can access remedial material and various assignments on email
d. Some students felt that actually face-to-face learning is more effective
e. Some students found obstacles on technical errors and internet balance.

\section{ACKNOWLEDGEMENT}

The authors express their deepest gratitude to the people who have contributed to this work, including the principal, the EFL teachers, and all students at SMK Muhammadiyah Barru. This research did not get funding from any party. 


\section{ABOUT THE AUTHORS}

Nashruddin, S.Pd., M.Pd. is an EFL lecturer in English Education Department at STKIP Muhammadiyah Barru. His ID Scopus is 57204543841. His research interests are on Education, English Learning and Teaching, and Sociolinguistics. Since 2017, he has published some research papers and one of them is published in Scopus indexed international journal.

Dr. Fiptar Abdi Alam, M.Si. is a senior lecturer and the chairman at STKIP Muhammadiyah Barru. His research interest is on Guidance and Counseling Education. His Sinta ID is 6197289.

Novalia Tanasy, S.Pd., M.Pd. is a lecturer is an EFL lecturer in English Education Department at Universitas Muslim Maros. Her research interest is on English Education.

\section{REFERENCES}

Ashby, E. (1972). The Fourth Revolution: Instructional Technology in Higher Education. A Carnegie Commission on Higher Education Report. New York: McGraw-Hill Book Co.

Barton, E. E., Fuller, E. A., \& Schnitz, A. (2015). The Use of Email to Coach Preservice Early Childhood Teachers. Topics in Early Childhood Special Education, 10(1), 1-13.

Barton, E. E., Pokorski, E. A., Gossett, S., Sweeney, E., Qiu, J., \& Choi, G. (2018). The use of email to coach early childhood teachers. Journal of Early Intervention, 40(3), 212228. doi: $10.1177 / 1053815118760314$

BBC. (2020). Coronavirus: Window of opportunity to act, World Health Organization says. from https://www.bbc.com/news/world-asia-china-51368873

Chang, Y., \& Hsu, Y. (1998). Requests on e-mail: A cross-cultural comparison. from http://dx.doi.org/10.1177/003368829802900206

Chun, D., Kern, R., \& Smith, B. (2016). Technology in Language Use, Language Teaching, and Language Learning. The Modern Language Journal, 100, 64-80.

Citizen, T. O. (2020). Human-to-human transmission of Wuhan virus outside of China, confirmed in Germany, Japan and Vietnam.

El-Sabban, F. (2015). Incorporating E-mail in Teaching Activities of the Nutrition Program at College for Women, Kuwait University: Assessment of a Five-year Experience. British Journal of Education, Society \& Behavioural Science, 5(1), 62-72.

Gallois, C., Ogay, T., \& Giles, H. (2005). Communication accommodation theory: A look back and a look ahead. In W. B. Gudykunst (Ed.), Theorizing about culture and communication (pp. 121-148). Thousand Oaks, CA: Sage.

Howe, N., \& Strauss, W. (2003). Millennials go to college: Strategies for a new generation on campus. Washington, DC: American Association of Collegiate Registrars.

Johnson, B., \& Christensen, L. (2008). Educational Research: Quantitative, Qualitative, and Mixed Approaches. Los Angeles: Sage Publications.

McLeod, R. H., Kim, S., \& Resua, K. A. (2018). The Effects of Coaching With Video and Email Feedback on Preservice Teachers' Use of Recommended Practices. Topics in Early Childhood Special Education, 38(4), 192-203. doi:10.1177/0271121418763531 
Moran, C., \& Hawisher, G. (1998). The rhetorics and languages of e-mail. In I. Snyder (Ed.), Page to screen: Taking literacy into the electronic era (pp. 80-101). New York: Routledge.

Oborn, K. M., \& Johnson, L. D. (2015). Coaching via electronic performance feedback to support home visitors' use of caregiver coaching strategies. Topics in Early Childhood Special Education, 35(1), 157-169.

Oomen, J., \& Early, A. D. (2015). Teaching in a Millennial World: Using New Media Tools to Enhance Health Promotion Pedagogy. Pedagogy in Health Promotion: The Scholarship of Teaching and Learning, 1(2), 95-107.

Press, C. (2020). CDC Confirms Person-to-Person Spread of New Coronavirus in the United States.

Purcell, K., Heaps, A., Buchanan, J., \& Friedrich, L. (2013). How teachers are using technology in their homes and in the classroom. 2020, from http://www.pewinternet.org/2013/02/28/how-teachers-are-usingtechnology-athome-and-in-their-classrooms/

Turnage, A. K., \& Goodboy, A. K. (2014). E-Mail and Face-to-Face Organizational Dissent as A Function of Leader-Member Exchange Status. International Journal of Business Communication, 1-15.

updates, W. c. (2020). Reported Cases and Deaths by Country, Territory, or Conveyance. from https://www.worldometers.info/coronavirus/ 